\title{
Edward Bates and Sons, 1897-1915: Tramping Operations in Recession and Recovery ${ }^{1}$
}

\section{Gordon Boyce}

Compared with liner companies, British tramp shipping firms have not been comprehensively analyzed by maritime historians, even though for extensive periods general trading vessels comprised a sizeable proportion of the national fleet as well as the Finnish, Norwegian and Greek merchant marines. ${ }^{2}$ In part, this unequal coverage is explained by the fact that many general trading enterprises were small and left few records, whereas the large liner companies were more durable and their corporate memories were preserved. Nevertheless, several British tramping outfits have attracted scholarly attention; these include Burrell, Turnbull, Radcliffe and Furness. Robin Craig noted that tramp shipowning generated impressive fortunes in the pre-1939 period. He cited George

${ }^{1}$ The research for this paper was supported by a Caird Fellowship generously provided by the National Maritime Museum, Greenwich. The author thanks participants in the Economic History Workshop hosted by Tim Hatton at Australian National University in 2008 and the Australasian Mining History Conference organized by Mel davies at Lithgow in 2009, as well as Mack Boot and two anonymous referees for helpful suggestions. Lewis Fischer kindly provided out-of-print works. This paper is part of a larger study of British tramp shipping.

${ }^{2}$ Some important works on national fleets include Gelina Harlaftis, A History of Greek-Owned Shipping. The Making of an International Tramp Fleet in the Nineteenth and Twentieth Centuries (London, 1996); Helge W. Nordvik, "The Shipping Industries of the Scandinavian Countries, 1850-1914," in Lewis R. Fischer and Gerald E. Panting (eds.), Change and Adaptation in Maritime History: The North Atlantic Fleets in the Nineteenth Century (St. John's, 1985), 117-148; and Yrjö Kaukiainen, $A$ History of Finnish Shipping (London, 1993). Robin Craig wrote a general history of tramp ships, Steam Tramps and Cargo Liners (London, 1980). Histories of British tramping firms include R.A. Cage, A Tramp Shipping Dynasty - Burrell \& Son of Glasgow, 1850-1939: A History of Ownership, Finance, and Profit (Westport, CT, 1997); J. Geraint Jenkins, Evan Thomas Radcliffe: A Cardiff Shipowning Company (Cardiff, 1982); Anne Long and Russell Long, A Shipping Venture: Turnbull Scott and Co., 1872-1972 (London, 1972): and Gordon Boyce, The Rise and Dissolution of a Large-scale Enterprise: The Furness Interests (St. John's, forthcoming).

International Journal of Maritime History, XXIII, No. 1 (June 2011), 13-50. 
and William Burrell, Walter Runciman, Maclay and Macintyre, Edward Hain, the Radcliffe brothers, Christopher Furness (later Lord Furness) and Edward Nicholas as highly successful "masters of the difficult art of tramp ship management." ${ }^{3}$ Yet little regarding the mysteries of this art has entered the historical record. What was involved in running itinerant trading vessels? The records of Edward Bates and Sons provide insights into the day-to-day operations, strategies and results of one small tramping firm in the pre-1916 period.

The evidence for the years 1897-1915 can be used to address two important themes in the history of British shipping. First, the period included the turn-of-the-century boom and the ensuing slump which Derek Aldcroft characterized as "the first major international shipping depression." ${ }^{4}$ The Bates records reveal how a small company coped with the highly unfavourable conditions that prevailed from 1901 to 1911 and benefitted from the subsequent recovery. These papers also allow some speculation regarding the position of the tramp sector as it approached World War I and the slump of the 1920s. Second, the company's documents provide evidence relevant to the debate regarding the importance of outward coal cargoes to the shipping industry. Contemporary observers, including Adam Kirkaldy, the Angier Brothers and a British Departmental Committee, thought that coal exports were vital in establishing and maintaining the nation's leading position in shipping. ${ }^{5}$ Craig suggested that "Britain's unique endowment of high quality steam coal was to become the most potent agent of Britain's supremacy in tramp steamships." ${ }^{6}$ According to Neil Buxton, coal exports (twenty-two million tons in 1886 and seventy-three million in 1913) improved performance by reducing outward ballast voyages. Sarah Palmer argued that while foreign operators dominated exports to northern Europe since the mid-nineteenth century, shipments to distant bunkering stations in the 1870s and 1880s helped establish Britain's lead in the tramping sector. She also found that Britain retained a tight grip on those

${ }^{3}$ Robin Craig, "Aspects of Tramp Shipping and Ownership," in Keith Matthews and Gerald Panting (eds.), Ships and Shipbuilding in the North Atlantic Region (St. John's, 1978), reprinted in Craig, British Tramp Shipping, 1750-1917 (St. John's, 2003), 37.

${ }^{4}$ Derek H. Aldcroft, “The Depression in British Shipping, 1901-11,” Journal of Transport History, 2nd ser., VII, No. 1 (1965), 14-23.

${ }^{5}$ Adam W. Kirkaldy, British Shipping: Its History, Organisation and Importance (London, 1914; reprint, Newton Abbot, 1970), E.A.V. Angier, Fifty Years' Freights, $1869-1919$ (London, 1920); and Great Britain, Parliament, Parliamentary Papers (BPP), "Report of the Departmental Committee on Shipping and Shipbuilding," 1918, XII, Cd. 9092.

${ }^{6}$ Craig, “Aspects of Tramp Shipping and Ownership," 22. 
non-European trades characterized by high-value imports and low-value coal exports. Both Palmer and Buxton believed that the slump in these outbound cargoes in the 1920s had a debilitating impact on tramping. ${ }^{7}$

In contrast, Knick Harley used quantitative data to show that coal exports did not enhance the profitability of British shipping because such outward shipments caused homebound freight rates to fall. ${ }^{8}$ He argued that most of Britain's coal was dispatched to northwestern Europe, and in these trades the share of total vessel departures by British shipowners fell relative to those of foreigners. Britain held a larger share of long-distance trades, but in contrast to Palmer, Harley argued that these routes attracted comparatively few coal shipments. Thus, by comparing changes in market share, he inferred that coal exports did not contribute to the competitiveness and efficiency of the British fleet. Harley's interpretation, however, is based on aggregate data complemented by "snap-shot" analyses of isolated two-way, outbound and inbound voyages, after 1890. Neither approach provides an impression of the importance of coal exports to individual firms over time or during the period in which Palmer believed the British tramp sector established its dominant position. The present study uses uninterrupted time series drawn from voyage accounts to develop a dynamic view of one company's operations, which also included cross-trading and multilateral voyages, within the context of later changes in the structure of the coal export business. ${ }^{9}$

The first part of the paper outlines the Bates family history and changes in their business operations from the mid-nineteenth century to the end of World War I. The second section examines the Bates fleet. Next, I analyze the numerous variables that tramp owners had to consider in deploying their tonnage. The fourth and fifth sections consider the firm's trades. The sixth part investigates the profitability of the Bates operations. A set of conclusions ends the essay.

${ }^{7}$ Neil K. Buxton, "Coalmining," in Buxton and Derek H. Aldcroft (eds.), British Industry between the Wars (London, 1979), 48-77; and Sarah Palmer, "The British Coal Export Trade, 1850-1913," in David Alexander and Rosemary Ommer (eds.), Volumes Not Values: Canadian Sailing Ships and World Trades (St. John's, 1979), 331-355.

${ }^{8}$ C. Knick Harley, "Coal Exports and British Shipping, 1850-1913," Explorations in Economic History, XXVI, No. 3 (1989), 311-338.

${ }^{9}$ The evidence consists of letter books written by Edward Bertram Bates (BAT 2/1-8), replies from Gilbert Thomas Bates (D 641/4/62), Voyage Accounts (BAT 7) and Movement Books (BAT 8). The BAT records are in the National Maritime Museum (NMM), Caird Library (CL), while the D 641 series is located at the University of Liverpool (UL), Department of Special Collections and Archives (DSCA). 


\section{The Bates Family and Business}

Joseph Bates (1796?-1846) began his career as a cloth manufacturer before becoming a wool merchant. In the 1830s he sent his sons, Joseph Jr. and Edward (1816-1896), to Calcutta to sell cloth and develop an import business. ${ }^{10}$ Edward returned to England and built up import/export operations in Liverpool. After 1848, he chartered and then purchased sailing vessels. Bates built up a substantial fleet (fifty-one sailing vessels by 1870) by purchasing inexpensive, second-hand ships to spread his risks and secured large profits by shipping Indian cotton during the American Civil War and chartering tonnage to the government during the Abyssinian campaign of $1868 .^{11}$

In 1870, Edward reformed his business as Edward Bates and Sons, taking into partnership his three sons: Edward Percy ("Ted," 1845-1899), Gilbert Thompson ("Tom," 1847-1917) and Sydney Eggers ("Syd," 1851-1924). The enterprise made its first investment in steamships in 1886. Bates and Sons also conducted a large merchant trading business between England and India and engaged in private banking operations, making loans to local businessmen and providing credit to commodity traders. ${ }^{12}$

The partnership gave Edward Sr. time to pursue politics, and he entered Parliament as a Conservative MP in 1871. He purchased three country estates and received a baronetcy in 1886 . Edward has been portrayed as a forceful, no-nonsense entrepreneur who built up a substantial enterprise and a large personal fortune (about $£ 200,000$ by the early 1860s). Despite his philanthropy, he was a disliked figure who remained outside the co-operative ethos that generally pervaded Liverpool's shipping networks. ${ }^{13}$ On his father's death in 1896, Edward Percy succeeded to his title.

Syd and Tom retired in 1898 and left the running of the firm to their elder brother Ted and his son, Edward Bertram ("Bertie," 1877-1903). After Sir Edward Percy died in an accident in 1899, his executors, which included his wife Constance, Tom and Bertie, ran the business until the latter and his brother Percy Elly (1879-1946) reached the age of twenty-five, when they

${ }^{10}$ A.H. Rowson, "Edward Bates - Shipowner," in Philip Bates, The Bates of Bellefield, Gryn Castle, and Manydown (Liverpool, 1994), 5.

${ }^{11}$ Graeme J. Milne, Trade and Traders in Mid-Victorian Liverpool: Mercantile Business and the Making of a World Port (Liverpool, 2000), 133-134.

${ }^{12}$ The Bates' India merchant business lasted until World War I, but the family remained involved in the Nigerian trade (in association with Brocklebanks from 1912) as well as banking until the 1960s.

${ }^{13}$ Milne, Trade and Traders: 133-134 and 160. See also Rowson, "Edward Bates," 15-17. 
were made full partners. Bertie joined the firm in 1898 and received in-house training. Percy acquired his initial business experience working for the Liverpool shipowners Johnston Brothers before joining Edward Bates and Sons in 1902. Bertie succeeded to his father's baronetcy and ran the family shipping business with advice from his uncles, Tom and Syd, as well as Mr. Sedgwick, a long-serving employee. In 1903, Bertie visited India where he contracted enteric fever and died at the age of just twenty-six. Percy, then just twentyfour, succeeded to the title and managed the business under the direction of his uncles and Sedgwick.

Sir Edward in total had seven sons. Cecil Robert (1882-1935), Austin Graves (1891-1961) and Maurice Halifax (1898-1925) pursued military careers; after their active service, Cecil and Austin filled minor roles in the business. The fourth, Frederick Alan (1884-1957), and the fifth, Denis Houghton (1886-1959), followed Percy Elly directly into business.

After 1900, the Bates worked closely with the Harrisons, Alfred Jones, the Johnstons and J. Welsford. All were based in Liverpool and, apart from Welsford, built up major shipping lines. Harrisons and Jones organized their enterprises as joint-stock companies. ${ }^{14}$ In contrast, the Bates' shipping interests remained a private partnership that managed ten separately-owned vessels and two ships controlled by the Idar Shipping Co. This structure, known as an "ownery," was very traditional; until the mid-nineteenth century many shipowners established single-ship enterprises that sold shares to network allies, as well as to the public, and used a management company that, through contracts, controlled vessel deployment in return for commissions. The Bates were unusual in that they retained a significantly larger proportion of the shares issued by their single-ship firms than other Liverpool shipowners who employed this corporate structure. ${ }^{15}$ Moreover, by the turn of the century, many shipowners were consolidating vessel ownership into a single firm that in most cases owned and ran the ships directly without a separate management company. ${ }^{16}$ The Bates (and their friends the Johnstons) adhered, however, to the old management firm-ownery structure.

${ }^{14}$ Francis E. Hyde, Shipping Enterprise and Management, 1830-1939: Harrisons of Liverpool (Liverpool, 1967), 99. Developing a group structure based on crossshareholdings, Jones controlled a series of joint-stock firms, each of which managed multiple-vessel fleets; see Peter N. Davies, The Trademakers: Elder Dempster in West Africa, 1852-1972, 1973-1989 (St. John's, 2000), 414.

${ }^{15}$ Milne, Trade and Traders, 152-161.

${ }^{16}$ Gordon Boyce, Information, Mediation, and Institutional Development: The Rise of Large-scale Enterprise in British Shipping, 1870-1919 (Manchester 1995), 7695. 
The family firm was also unusual in that as late as 1900 it continued to operate six sailing vessels and six steamers. In contrast, nearly all the family's allies employed steamers exclusively (Welsford managed three steamers and one sailing ship). While the operation of a mixed fleet was reminiscent of a strategy widely employed forty or fifty years earlier, it made good business sense. The steamers provided medium-distance tramping services to India, the Black Sea and South America, as well as seasonal transatlantic services jointly with Welsford and the Johnstons, while the sailing vessels worked profitably in the long-haul trades to the Pacific. Nevertheless, by 1905 the Bates had sold the last of their sailing vessels and focused on steam. Thus, when Percy became the chief manager following Bertie's untimely death, Bates and Sons was a small-scale tramping outfit that was dwarfed by Liverpool liner operators like Elder, Harrison, Leyland, Cunard and White Star.

In 1911, the Bates acquired a fifty percent stake in T. and J. Brocklebank, an old Liverpool firm that ran lines between Britain and India. Seven years later they exchanged this investment for a 19.5 percent interest in the Cunard Steamship Company, a largely publicly-owned enterprise that had become something of a national institution after it secured government assistance to fight off a takeover attempt by the J.P. Morgan interests in 1902-1903. ${ }^{17}$ Denis and Frederick then became directors of the new parent firm (Austin joined them later), and Sir Percy, who had been a Cunard director since 1910, became its deputy chairman in 1922 and chairman in 1930. He served in this capacity until his death in 1946; he was succeeded by Frederick, who held the office until he passed away in 1953, and Denis, who was chairman until his death in 1959. Finally, Denis' son, Philip, held positions in the Cunard group and became deputy chairman before retiring in 1983. While the long service rendered by the Bates family to the Cunard group is of interest, the present analysis focuses on their tramping business up to $1915 .{ }^{18}$

\section{The Bates Fleet}

Bates operated a mixed fleet (see table 1). In 1900, the steam fleet had an average age of just over 5.5 years. It consisted of three medium-sized cargo carriers and three large ones; one of the latter, Irada, was an expensive, twin-

${ }^{17}$ Francis E. Hyde, Cunard and the North Atlantic, 1840-1973: A History of Shipping and Financial Management (London, 1975), 137-148 and 166; Vivian Vale, The American Peril: Challenge to Britain on the North Atlantic, 1901-1904 (Manchester, 1984); and Boyce, Information, Mediation, and Institutional Development, 99-104 and 128. By 1919, Cunard had acquired eight firms; its combined fleet of more than 558,000 gross registered tons (grt) made it one of Britain's five largest shipping groups.

${ }^{18}$ See Boyce, "Language and Culture in a Liverpool Merchant Family Firm, 1870-1950,” Business History Review, LXXXIV, No. 1 (2010), 1-26. 
screw unit built especially for the cotton trade. Apart from Irada, which was built near the peak of the turn-of-the-century shipbuilding cycle (see below), the other ships were probably acquired at modest cost. With Irada again the exception, the fleet consisted of what contemporaries called "handy" vessels, that is, versatile ships of a size suitable for various trades. When the decadelong shipping slump struck in 1902, the fleet was probably quite well depreciated; using the usual benchmark of allocating five percent per annum, it would have been written down to about 62.5 percent of its original cost. Thus, the Bates would have been in good shape to weather the recession. By 1914, the fleet consisted of four aging ships.

Table 1

Bates Fleet, 1900

\begin{tabular}{lccllrl} 
& \multicolumn{2}{c}{ Steamers } & & \multicolumn{3}{c}{ Sailing Ships } \\
Ship & Built & NRT & Other & Ship & Built & NRT \\
Idar & 1888 & 2595 & & Cabul & 1877 & 1397 \\
Imaum & 1890 & 2706 & & Heart & 1877 & 1400 \\
Iran & 1896 & 4066 & & Kelat & 1881 & 1822 \\
Istrar & 1896 & 2979 & & Kistua & 1883 & 2149 \\
Imani & 1897 & 4582 & & Ladakh & 1883 & 1908 \\
Irada & 1900 & 6250 & twin screw & Manydown & 1884 & 2381
\end{tabular}

Notes: Idar and Imani were managed by J. Welsford; Idar was sold to Welsford in 1905

Source: Lloyd's Register of Shipping, various years.

The sailing fleet in 1900 was already very old and comprised two small and four medium-sized vessels. The family likely began disposing of this component of its fleet to avoid escalating maintenance costs and possibly because it was becoming difficult to obtain insurance. ${ }^{19}$ Kelat was the last to be sold (in 1904); thereafter, the family focused on steam tramping.

\section{Mastering the "Difficult Art of Tramp Ship Management"}

The principal source for this section is a series of letters written by Edward Bertram "Bertie" Bates to his father and uncles, Tom and Syd. His correspondence consists of informal situation reports concerning ship movements, ship allocation decisions and market conditions. Written by a young man learning the business, the letters provide a unique source that reveals the complex mix

\footnotetext{
${ }^{19}$ At about this time, the Directors of James Nourse and Co., experiencing severe difficulty obtaining insurance coverage, disposed of its sailing ships. NMM, CL, NOU 13/1, 27 February 1907.
} 
of variables that had to be mastered to maximize profits. Another set of letters, written by Uncle Tom in reply to Bertie, and following the latter's death to his nephew Percy, contain guidance based on long experience running tramps.

While he sometimes reported on the family's merchant trading and banking activities, Bertie's principal day-to-day responsibilities included monitoring changes in the freight markets across much of the world, identifying developments that might affect demand for shipping space, finding work for ships, tracking their movements and liaising with agents and charterers. When a ship reached Liverpool, he inspected it, saw to any repairs and oversaw its discharge and loading. Bertie purchased bunkers, an activity that called for a firm grasp of conditions in the coal market, knowledge of differences in quality and contacts with suppliers. ${ }^{20} \mathrm{He}$ also applied this expertise when he bought outward coal cargoes on the firm's own account. At annual intervals he arranged the fleet's insurance cover, and from time to time he undertook the purchase and sale of vessels. Young Bertie operated in a complex and rapidly changing business arena.

As for any tramp manager, Bertie's main task was to keep all the ships constantly employed at the best rates available. Time was money, and given the large amounts of debt needed to finance their fleets, shipowners were among the earliest businessmen to employ accounting techniques, such as calculating the return on capital, that reflected a prime concern with the passage of days. ${ }^{21}$ To maximize profits, tramp owners had to minimize time in port, eschew ballast voyages and arrange proper maintenance to lessen the chance of breakdown. They sought to avoid tying up ships at poor rates when more favourable conditions might become available elsewhere. Attention to all items of expense was vital; they calculated earnings and costs per day.

Demand for shipping space was derived from world trade, and there were numerous sub-markets tied to particular locales or commodities. Freight rates fluctuated widely over time and space. Wars, outbreaks of disease, strikes and poor weather could have a profound impact on the demand for ships in a specific place at a specific time. ${ }^{22}$ Thus, what might be called "fleet

${ }^{20}$ Coal varied widely in terms of quality and burning characteristics. South Wales steam coal was the best and most expensive. More precise qualitative specification was an important factor in the spread of regional coal exchanges from about 1870. See Roy Church, The History of the British Coal Industry. Vol. 3: Victorian Preeminence, 1830-1913 (Oxford, 1986), 48-51 and 79.

${ }^{21}$ Gordon Boyce, "Accounting for Managerial Decision-making in British Shipping, 1870-1918, " Accounting, Business, and Financial History, V, No. 3 (1995), 360-378.

\footnotetext{
${ }^{22}$ Similarly, demand for new ships was tied to, but lagged, changes in freight rates; and the timing of vessel building decisions was very important. For a discussion
} 
positioning," which involved having vessels in places where cargoes were abundant at high rates and where the volume of shipping space available was scarce, was the key skill of the tramp owner. Optimal positioning required knowledge about commodity flows, harvest times, weather conditions and the activities of other owners. Moreover, as in the game of chess, players had to think several moves ahead of their current situation.

At most ports, a type of futures market determined freight rates months in advance. Prices reflected anticipated cargo volumes and the supply of shipping. For example, in 1900 Bertie reported to Uncle Syd that Bombay was quoting twenty-one shillings for March loadings but only eighteen shillings for April. ${ }^{23}$ If a shipowner believed that the rates for April were likely to fall further in the following weeks, he could lock in a cargo at eighteen shillings and avoid any further price deterioration (if the opposite occurred, of course, he would forego profits). This tactic removed future uncertainty and could be used as a competitive weapon to deprive other owners of access to at least some cargo in April. In one instance, Bertie booked a homeward cargo for the sailing vessel Cabul from San Francisco at forty shillings just as the vessel was due to leave Rotterdam on its outward trip to Puget Sound at the much lower rate of fifteen shillings per ton. ${ }^{24}$ Although the passage time of the sailing vessel could not be predicted, he could therefore estimate the receipts for the round trip with accuracy and be sure that no rival was able to take the lucrative return freight. The futures market conditioned positioning strategies.

Shipowners could hold off booking cargo forward in order to deprive the market of knowledge about their vessel's arrival in the hope that increasingly desperate shippers would bid up rates. On one occasion, Sedgwick inadvertently took a shipment at sixteen shillings from a friendly Liverpool firm. As Bertie reported:

Alexander at present is in a fine rage but no doubt will simmer down \& then Sedgwick will see him about it. It seems Alexander missed the market for his boat when freights were high refusing $30 /-\&$ therefore I fancy he was in a bad temper about this to start with $\&$ then finding that purely by accident we had cut in \& taken what cargo was left he naturally did not like it. Sedgwick is very cut up about it but I do not think it will be serious of course. If we had known Alexander

of shipping and shipbuilding cycles, see Sidney Pollard and Paul Robertson, The British Shipbuilding Industry, 1870-1914 (Cambridge, MA, 1979).

${ }^{23} \mathrm{NMM}, \mathrm{CL}, \mathrm{BAT} 2 / 4,12$ March 1900 (to Syd).

${ }^{24}$ Ibid., 3 March 1900 (to Father). 
was competing for the cargo he would have either refused the business altogether or arranged with Alexander to work the rate up. ${ }^{25}$

This example shows that tramp markets were far from "perfect;" by colluding and not accepting a given rate, shipowners might be able to obtain more favourable terms.

Sometimes Bertie got "caught" with ships out of position in relation to available cargo. In early 1900, he sent Imani to Bombay, but by the time it was close to that port he had been unable to "fix" (contract for) a return cargo, and the prospect that further cargoes might become available was remote. In this situation, any merchants who had goods awaiting shipment would recognize that Bertie was desperate and would bid down rates. To make matters worse, by the time Imani arrived in April, the rice boats from Rangoon would be calling at Bombay to fill up any empty space they might have. ${ }^{26}$ Bertie tried to engage a partial load of 3000 tons at seventeen shillings for Marseilles and nineteen shillings for Antwerp, but by the time the ship arrived he could only get sixteen and eighteen shillings, respectively.

In May 1900, Bertie sought to avoid a similar outcome by arranging a cargo for the sailing vessel Manydown from San Francisco at thirty-seven shillings six pence per ton to Europe. ${ }^{27}$ The object lesson behind this tactic was the situation in which he found himself when another vessel, Kelat, arrived at the same port unfixed and was forced to take a pitiful homeward freight. By fixing Manydown ahead of its arrival Bertie avoided having to buy a cargo and thereby take additional risks arising from uncertain commodity market conditions. While the thirty-seven shillings six pence rate was not particularly high, the ship, which was probably worth about $£ 10,000$ at most, would earn a $£ 3000$ profit. Although confined to low-value, long-distance trades, Bates' sailing vessels were good earners at this time.

Indicating how difficult it was to predict movements in rapidly changing freight markets, Bertie reported to Uncle Tom that "we have made a mistake in waiting" to book cargo for Istrar on the Bombay-Antwerp run. By 30 April 1902, he had booked 4000 tons at thirteen shillings per ton and would have to accept twelve shillings six pence for the rest. ${ }^{28}$ Accurately foreseeing a dismal outcome, Bertie commented that "Truly business is discouraging nowa-

${ }^{25}$ Ibid., BAT 2/1, n.d. [c. 27 June 1898] (to Father).

${ }^{26}$ Ibid., BAT 2/4, 14, 16 and 24 March 1900 (to Tom).

${ }^{27}$ Ibid., 20 May 1900 (to Syd).

${ }^{28}$ As a ship approached a fully loaded condition, if cargo was scarce owners often cut rates to complete the process and despatch the vessel. 
days." The voyage accounts show that the ship earned only $£ 93$ on the eightyfour-day trip. ${ }^{29}$

Constantly shifting conditions induced Bertie to evaluate alternatives and to think several months ahead. In June 1900, poor results in the Baltimore trade, a seasonal route that Bates operated in partnership with the Johnstons, compelled Bertie to seek other employment. He was trying to book grain from Galveston for the Bates' new ship Irada, but he anticipated that should his efforts fail he could deploy it on a charter with Elder Dempster for a run from New Orleans to Rotterdam. At this time the grain trade from Odessa appeared to be the brightest source of work, but Bertie's ships were out of position. As he wrote to Uncle Syd,

This Odessa business is going to be the best thing in the market \& if I can get things straightened up \& see where our boats are going I shall on first opportunity fix Imaum or Idar out to Port Said \& home from Odessa, to Rotterdam at 12/to $13 /$ - for August/September loading. It will leave a very good turn over as things go nowadays. Cotton charters at $47 / 6$ are nothing like as good. ${ }^{30}$

Thus, with one ship headed to the US, the young manager compared the grain trade with a cotton charter and with other vessels en route to Europe for discharge. He decided that the Odessa trade was superior to cotton charters and sought to "straighten out" the fleet's alignment to take advantage of the good rates he believed would prevail in the grain trade two or three months in the future.

Bertie constantly analyzed the relative attractions of various trades as rates and cargo volumes ebbed and flowed, and he sought advice from senior family members. He wrote to his father in September 1899 that "I have worked out for you the 2 voyages below for comparison. Idar 11/- to Port Said \& 11/6 Odessa to Rotterdam leaves $£ 2,600$, or $16 /$ - to Bombay \& 16/- to Antwerp leaves $£ 2,740$; Odessa Voyage 60 days, Bombay 85." While the first option was more profitable than the second in terms of earnings per day ( $£ 43$ vs. £32), the lifting of quarantines at Port Said and Odessa clinched the decision to send Idar to Odessa, since the outbreak of plague had scared off other

${ }^{29}$ Ibid., BAT 2/8, 8 (to Tom) and 30 (to Syd) April 1902; and BAT 7, Istrar, voyage 32 .

${ }^{30}$ Ibid., BAT 2/5, 27 June 1900 (to Syd).

${ }^{31}$ Ibid., BAT 2/3, 17 June 1900 (to Father). 
shipowners and led to excess demand for shipping space. Bertie believed that homebound rates would improve further. ${ }^{32}$

The middle of 1898 was an anxious time for shipowners, and Bertie struggled to find employment for his ships. In June 1898, he told his father that:

Istrar freights seem to be as bad as they can be \& everybody is hard up for employment. I do not think this stagnation will last long but Istrar is due in Rotterdam tomorrow or Sunday \& with coal strike on we are rather in a corner as Wills [a coal merchant whom the family frequently worked with] cannot load her \& will not give us a coal cargo from here. Welsford says he can offer us nothing across the Atlantic except cattle trade from Boston which one would have to stop in 4 or 5 voyages to do any good [because of the cost of fitting out the ship]. I have tried everything I can think of \& Sedgwick also thinks that the only thing to be done is to ship a cargo from the Tyne on own a/c of Davies Hartley coal. We are trying to get a cargo off Laurences for 12/9 which we shall get in Bombay 18 Ruppees for, which @1/3.5 ex. Wills $+10 / 4$ freight. We should get more than 8 Ruppees in Karrachee \& if the coal is not sold before she leaves we have Port Said \& Aden to fall back on, as coal is in demand there for bunkering. We should make $£ 600$ on the round [trip] with 15/- home from Bombay the rate at present there is $17 / 6$ 18. It is not brilliant but under the circumstances might be worse $\&$ beggars cannot be choosers. ${ }^{33}$

Bertie's desperation was reflected in his willingness to buy a coal cargo and accept the risk that prices in Bombay, Aden or Port Said might fall by the time the ship arrived. Sale in Bombay also raised a currency risk.

After learning that Laurence's coal was "absolutely" unsuitable for the Bombay market, Bertie and Sedgwick approached five other coal merchants before buying a cargo from Lamberts for Port Said at an implied freight rate of nine shillings. From there, Istrar would proceed to Odessa to take a fixture at eight shillings per ton instead of going to Bombay where rates had fallen further and where "one man has failed already." 34

\footnotetext{
${ }^{32}$ Ibid., n.d. [c. 5 October 1900] (to Father).

${ }^{33}$ Ibid., BAT 2/1, 17 June 1898 (to Father).

${ }^{34} \mathrm{Ibid}$., 20 June (to Father), 22 June (to Syd) and 27 June 1898 (to Father).
} 
The Bates' practice of buying cargoes was reminiscent of the combined merchant-shipowner operations of the first half of the nineteenth century before functional specialization caused the separation of the two activities. ${ }^{35}$ Although important changes were still unfolding in the coal trade (see below), at the turn of the century the family's expertise in commodity trading generated benefits for its shipping arm. Knowledge of markets for bulk items and the ability to assess currency and commodity price risks enabled the Bates to keep their vessels "moving," that is, working in situations where laying-up was the only alternative.

In addition to giving the firm a competitive advantage in coping with recessions, commodity trading helped the Bates to adjust to changes in shipping patterns. This capability sustained mixed-fleet operations. For example, by 1901 the rice trade was shifting from sail to steam. While the Bates records do not disclose the reasons for the change, it is likely that growth in the volume and value of the commodity probably played a role. Nevertheless, Bertie had positioned a sailing vessel, Herat, to arrive at Rangoon at the height of the rice season in February only to find that rates for this type of ship were so far below those offered for steamers that it made no sense to have Herat load rice. Since rates for sailing vessels were better elsewhere, Bertie shifted the vessel to Newcastle, NSW, and bought a coal cargo for sale on the west coast of South America where he could get a good rate on a nitrate cargo. He estimated that the freight rate equivalent (that is, the profit on the sale of the coal) would be twenty-four shillings per ton and that the return rate on the nitrate shipment would be thirty-one to thirty-two shillings per ton. The records do not disclose the overall result of the voyage, but Bertie was confident of a good outcome when he made the deployment. ${ }^{36}$ The incident shows how their commodity business - they also bought salt and wheat cargoes - enabled them to find employment for sailing vessels as the fringe of steam operations shifted outwards.

The Bates sailing fleet ran in long-distance trades, including those between Europe and New York to Australia, the US west coast, South America and across the Pacific. The ships also served small, out-of-the-way ports like Mauritius and operated in the cross-trades, such as between Rangoon and New York, where steam services were not yet viable. In addition to coal, the vessels carried low-value goods like cement, wheat, salt, rice and nitrate, as well as some higher-value products such as sugar and hemp. Some voyages produced spectacular profits in relation to the capital employed - Manydown's voyage cited above is a case in point - but over their working lives some ships

\footnotetext{
${ }^{35}$ Simon P. Ville, English Shipowning during the Industrial Revolution: Michael Henley and Sons, London Shipowners, 1770-1830 (Manchester, 1987): 3-5.

${ }^{36}$ NMM, CL, BAT 2/6, 13 February (to Syd) and 14 February 1901 (to Tom).
} 
did not pay their way. For example, the Bates paid $£ 24,442$ for Sadakh in 1883 , but by 1898 it had earned only $£ 12,000$ and was worth just $£ 7000$ $8000 .{ }^{37}$ One reason the Bates kept running their sailing vessels was because occasionally they obtained favourable freight rates. As Bertie told Welsford in early 1901, "[a]n extraordinary aspect of the current slump is that sail rates remain firm." ${ }^{38}$ Nevertheless, the fleet was getting old, and one year earlier Bertie was of the opinion that while Heart, built in 1877, could earn about $£ 1500$ to $£ 2000$ per annum and was worth about $£ 8000$, it should be disposed of soon; indeed, before rates had risen a few years previously the vessel had been "unsellable." ${ }^{39}$ By 1901, the sailing fleet was nearing the end of its working life, and rising repair bills no doubt hastened the family's decision to sell these vessels over the next few years.

Overseeing maintenance was one of Bertie's many duties. Vessels with unclean hulls wasted coal and drove up bunker costs. Breakdowns in port caused delays, and equipment failure at sea could result in the loss of a vessel. Ships were sent to the dry-dock regularly to have their hulls cleaned and repainted if necessary; how frequently is not known precisely, but Bertie informed his father that Idar had not been dry-docked for eight months, suggesting that this was a long interval. ${ }^{40}$ On 15 June 1898, Bertie informed Uncle Tom that because Iran needed to be docked and painted it could not sail until the sixth or seventh of the following month, indicating that this type of maintenance required three weeks. A later letter revealed that routine cleaning took a week ${ }^{41}$ When ships were dry-docked for cleaning, their propeller shafts were inspected, since if this component failed, a vessel would be incapable of propulsion. If possible, repairs of damages were carried out at home where costs were lower, but while insurance covered the attendant expense, premiums might rise and the consequent cost of delay was borne by the owner unless another party was responsible.

Loading and discharging rates also determined the time a vessel spent in port and hence generated no earnings. Loading times varied according to commodity; it generally took between seventy-two and 150 hours to load a

\footnotetext{
${ }^{37}$ Ibid., BAT 2/1, 15 June 1898 (to Father).

${ }^{38}$ Ibid., BAT 2/7, 15 March 1901 (to Welsford).

${ }^{39}$ Ibid., BAT 2/5, 15 September 1900 (to Syd).

${ }^{40}$ Ibid., BAT 2/3, 6 July 1899 (to Father).

${ }^{41}$ Ibid., BAT 2/1, 15 June 1898 (to Father) and BAT 2/2, 6 March 1899 (to
}

Tom). 
coal cargo, but cement took ten days. ${ }^{42}$ As Bertie complained to Tom, Iran "had the worst cargo for discharging I have ever seen from Baltimore entirely consisting of lumber, cotton, pig iron with a few odds \& ends in tobacco, sheep feed etc not an oz of grain in her." ${ }^{43}$ Discharge rates depended on the size of the ship, port facilities, congestion and whether overtime was needed. Some of these variables could be controlled by specifying which ports and the number that could be used on a charter voyage. Thus, Bertie cautioned Welsford, who was arranging a government charter to South Africa, "I wish you to make them understand that we do not care to go to ports we know nothing about and that it is not so much a question of price as moderate detention \& a good rate of discharge." ${ }^{44}$ Iron took a long time to discharge, and Bates' charters with Elder Dempster, for example, specified that a maximum of 1250 tons of this good could be carried on each voyage. ${ }^{45}$ Contracts also specified the number of loading days allowed before demurrage could be claimed. Indeed, Bertie informed Uncle Syd that few merchants guaranteed loading days in contracts, but he made it a policy to deal only with those who did. ${ }^{46}$ Delays could have serious consequences; they might cause a vessel to miss previously arranged fixtures at the port of discharge and upset a whole sequence of positioning decisions concerning several vessels. Bertie was often compelled to "stir up" merchants who were slow in bringing cargo forward. Some ports acquired reputations for poor service; Bertie referred to Hull as "a one horse place" where the loading of coal was extremely slow and required the "stirring" of merchants. ${ }^{47}$

As a general guide to decision-making, Bertie compiled a schedule of routine charges levied at frequently used ports. ${ }^{48}$ This comparative reference tool generated organizational memory. Other tramp owners also drew up reference books listing a variety of commodity-specific and seasonal variables that shaped vessel deployment.

${ }^{42}$ Ibid., BAT 2/2, 20 April 1899 and 13 February 1900 (to Tom).

${ }^{43}$ Ibid., 9 March 1900 (to Tom).

${ }^{44}$ Ibid., BAT 2/3, 5 January 1900 (to Welsford).

${ }^{45}$ Ibid., BAT 2/6, 25 April 1901 (to Tom).

${ }^{46}$ Ibid., BAT 2/5, n.d. [c. 2 July 1900] (to Syd).

${ }^{47}$ Ibid., BAT 2/1, 4 July 1898 (to Father).

${ }^{48}$ Ibid., 13 June 1898 (to Father) and BAT 2/5, 9 July 1900 (to Syd). James Nourse also developed a similar document; see NMM, CL, NOU/5. 
Aligning specific ships with the cargo flows emanating from particular ports was an important consideration in determining employment. For example, Iran was too large for Newcastle-upon-Tyne and Odessa. ${ }^{49}$ The flows of coal and grain from these centres suited smaller ships. Some of Bates' vessels were designed for specific trades even though they operated as tramps in the "off season." Thus, Indore was constructed to meet demands imposed by the mixed-cargo flow from Baltimore, while the large Irada, whose innovative design Bertie's father had devised, was built for the cotton trade. ${ }^{50}$ Design specialization generated important efficiencies in a particular commodity trade but imposed a trade-off by limiting employment opportunities in markets characterized by changing cargo flows and volatile freight rates.

As in the shipping market, a futures component also influenced bunker prices. When Bertie suspected that prices would rise, he contracted ahead to accept specified quantities per month (contracts allowed for some flexibility in the quantities taken; see below). Conversely, if he felt a fall was likely he bought coal as needed:

Coals are easier \& these colliery chaps [who] are trying to contract bunkers next year at 18/- would take 17/- I think. I will not touch it at these figures, although [sic] I do not think we shall see coals as low as last year for a while. I shall work off my present contract with Llanbradach as quickly as I can \& start next year with as little coal bought as possible unless these colliery chaps come down to $15 /-.^{51}$

As Bertie's letter indicates, it was sometimes possible to get collieries to supply larger quantities in certain months and thereby "work off" a contract. Bertie was fortunate when he could do so for, as he learned, Elder Dempster had large quantities of bunkers "around their necks" at a contracted price of twenty shillings per ton when market prices had fallen to fourteen shillings. ${ }^{52}$ Bertie used multiple sources for bunkers to ensure reliable supplies and to play off one colliery against the others.

Coal is very stiff. I don't want to run out so I have offered to take 5000 tons from Llanbradach at 19/6 net August onwards

\footnotetext{
${ }^{49}$ Ibid., BAT 2/1, 7 and 22 September 1898 (to Tom).

${ }^{50}$ Ibid., BAT 2/4, 30 May 1900 (to Tom).

${ }^{51}$ Ibid., BAT 2/6, 5 December 1900 (to Tom).

${ }^{52}$ Ibid., BAT 2/7, 28 March 1901 (to Syd).
} 
he agrees...I will accept provided I am not tied down to equal quantities \& can take it when I like in reasonable quantities...I don't like [to] have one string to my bow \& I think it is convenient sometimes to be able to make favour of getting bunkers elsewhere to Pratt [sic]...Current prices for South Wales are anything from $21 / 6$ to 28 according to quality. ${ }^{53}$

Coal from South Wales was of the highest quality and commanded a premium price.

The market for bunkers could be upset by a number of factors. Heavy purchasing by the Admiralty at the outbreak of the Boer War pushed up prices. Colliery strikes also caused havoc: not only did they make it difficult to bunker the fleet, but the outward coal carrying trade was disrupted. Even if a labour disruption was local and coal could be purchased elsewhere, vessel positioning was disturbed. As Bertie told Tom, "the coal strike has been driving the boats to unsuitable ports like Hull and Newcastle which no doubt is the cause of their not getting quick dispatch." 54 The strike threatened voyage cancellations. A worried Bertie told Tom that "this strike is very awkward. Istrar was to have gone to Colombo with a cargo of coals @14/6 of course this will be out of the question if coal strike lasts." 55 For the Bates, bunkers were the most significant variable cost, representing nearly twenty-seven percent of total voyage costs. ${ }^{56}$ It is clear that by multi-sourcing and dealing repeatedly ("making favour") with the same group of collieries, Bertie was able to contain fuel costs.

Although admittedly thin (the voyage accounts include data only from about 1911 onwards), there is evidence that the Bates engaged in repeat contracting for Europe-bound cargoes and those shipped between Eastern ports. The fleet carried coal for Turner and Co. to and from Indian ports. In the rice trade from Rangoon, Bates vessels shipped for Mohr Bros., "RJ \& Co." and the Arracan Co., while from Bassein they shipped for Biehinawm Bros. They conveyed mixed cargoes from Bombay for Chugodas, D.W. Cling and, significantly, for T. and J. Brocklebank, a firm in which they took a sizeable stake in 1911. Serving these companies apparently did not create any conflict with the Bates' own merchant activities. How in practice the Bates drew the

${ }^{53}$ Ibid., BAT 2/5, 15 June 1900 (to Tom).

${ }^{54}$ Ibid., BAT 2/1, 13 September 1898 (to Tom).

${ }^{55}$ Ibid., 15 June 1898 (to Tom).

${ }^{56}$ Calculated from ibid., BAT 7. For the Johnstons' tramp operations in 1913, fuel accounted for 23.6 percent; see Furness Withy and Co., Legal Documents. 
line between competition and co-operation in these trades is not clear, but such juggling occurred in many maritime networks without generating difficulties. ${ }^{57}$

Repeat dealing was also evident in the Bates' chartering work. The firm hired out its ships repeatedly to two Liverpool-based firms, Elder Dempster and Alfred Holt and Co., and to Cayzer Irvine in Glasgow. These charters came in a variety of forms. Time charters involved hiring out a ship for a specified period with the charterer meeting all operating expenses and having control over the use of the ship within the limits established by the contract. In circumstances such as those that prevailed in mid-1900 when costs were extremely high, time charters were very advantageous to owners. Noting that the price of coal was forty shillings, Bertie told Syd that these contracts were a "boon" because had the vessel hired out been deployed in normal tramping operations, serious losses would have resulted.$^{58}$ Under a voyage charter, the merchant paid a fixed tonnage-based rate for a specific voyage, one-way or round trip, while responsibility for operating costs fell to the owner. These agreements stipulated the number of ports that could be visited, loading and discharge days and limits on the amount of difficult-to-handle goods. Sometimes voyage charters were run on a participating basis where the owner and hirer shared the profit or loss. Concerning a joint charter with Elders set up in late 1900 , Bertie felt that with freights so "dull" the deal was the best employment possible even though the rate was much lower than the one negotiated the previous year: "she will make $[£] 1500$ on the voyage." 59 Time charter parties included compensation for early termination; such clauses provided shipowners with not only a safeguard but also a source of considerable potential gain. The American Line chartered Ikbal for two years at eleven shillings per ton per month with an option to cancel after one year on payment of $£ 4000 .{ }^{60}$ In booming markets, fixed-term charters could deprive an owner of earnings that could have been made in normal operations, and tramp managers who believed that rates would continue to rise added an extra margin to cover their risks and entertained only fixtures of short duration. When freights were tumbling, as in early 1902, charters provided insulation against further falls. Apologetically, Bertie told Syd that "India Office have taken Idar at 10/3, it was the best I could do for her, either that or lay up \& I do not fancy that." ${ }^{1}$

\footnotetext{
${ }^{57}$ See Boyce, Information, Mediation and Institutional Development, 176-197.

${ }^{58} \mathrm{NMM}, \mathrm{CL}, \mathrm{BAT} 2 / 5,23$ August 1900 (to Syd).

${ }^{59}$ Ibid., BAT 2/6, 12 December 1900 (to Tom).

${ }^{60}$ Ibid., BAT 2/7, 25 April 1901 (no addressee).

${ }^{61}$ Ibid., BAT 2/8, 16 April 1902 (to Syd).
} 
Mothballing a ship was the last resort for any tramp operator. In pursuing this course they still incurred capital costs and fixed expenses, which in the case of Imani included a laying-up cost of $£ 350$ per month, or $£ 4200$ annually, on a vessel that cost $£ 55,000$ two years earlier, a heavy loss indeed. ${ }^{62}$ In 1908-1909, the Bates laid up Iran for six months, although they made the best of a bad situation by having it surveyed during that time. ${ }^{63}$

The evidence available indicates that the charter business was complex. When Bertie ventured into trades with which he was unfamiliar, he quoted high rates. In response to an offer from Elder Dempster to hire Imaum for a trip from New Orleans to the Cape for the fixed sum of $£ 7500$, with the hirer paying all expenses, Bertie indicated to Syd that "[i]t is not bad business but when we go out of our [usual] trades we don't do it for nothing [sic]." He countered with a bid of $£ 8500$ for calls at two ports, a payment of $£ 250$ for each additional port and escalating fees if unloading took over seven days. ${ }^{64}$ When Bertie could not gauge uncertainty, he eschewed certain sectors of the market. One complex field was hiring to the government: "I have not got the nerve to go into this sort of game blindly." ${ }^{65}$ Bertie understood his limitations and recognized when he had much to learn.

Ordering new tonnage was a task that was carried out infrequently, but it required high-level skills in judging the market, devising specifications that would suit particular trades (or better yet yield competitive advantages) and negotiating with shipyards. The timing of purchases was crucial to longterm profitability. Ordering in recessions when prices were low enabled owners to deploy new and efficient units as freights rose. Apart from the difficulty of timing purchases, shipowners often lacked the funds or the nerve to build against the cycle. A few figures stand out for their counter-cyclical strategies, Runciman and Furness being among the most noteworthy. As a result, many owners built more or less in line with the market. In a different context, Tom advised Bertie that "you will find as you go on that you will make money in doing different [sic] to others \& running your own line instead of following them ie sell when everyone is buying and buy when all are sellers."

Vessel design required knowledge of both technology and the commercial significance of certain variables. Commenting on different policies regarding one such variable - speed - Tom informed Bertie that:

${ }^{62}$ Ibid., 7 May 1902 (to Tom).

${ }^{63}$ Ibid., BAT 7, Iran, voyage 56.

${ }^{64}$ Ibid., BAT 2/4, 12 March 1900 (to Syd).

${ }^{65}$ Ibid., 25 April 1900 (to Syd).

${ }^{66}$ UL, DSCA, D 641/4/62, 26 November 1901 (Tom to Bertie). 
[Thomas] Hughes [of the Harrison Line] has always gone for slow boats, average 10 knots in all weather was a fast one in fact all the cargo [ship] owners did the same or worse 7 knots was ample for most. We always wanted power \& speed - The first one, the old Iran could do 11 in fine weather and seldom much below 10 in the worst of weather and this in 1886 was considered by some absolute folly for a cargo boat. ${ }^{67}$

The Bates used speed as a competitive weapon, and in Tom's view with success.

In 1901, the uncle thought it was best to build relatively small ships like Iran (just over 4000 net registered tons [nrt]), whereas Bertie favoured much larger types like the new Irada (6250 nrt). After building the big boat and running it for eight months, the nephew found that it outperformed smaller ships. Moreover, John Hughes, who as Tom revealed earlier favoured small vessels, admired Irada.$^{68}$ Bertie felt that the only types of ship to build at the time were large Irada types or much smaller Istrars (2979 nrt); any type between these extremes, such as Iran, was not as profitable. He described Irada as a "liner-tramp" and stated that it beat smaller units when markets were weak. ${ }^{69} \mathrm{He}$ planned to discuss the building of another large vessel with the Belfast builders Workman Clark, who could deliver the unit before the start of the cotton season and who quoted a price of $£ 124,000$, whereas another yard (Barclay Curle) offered $£ 133,000$. Tom indicated that he "would sooner have 2 Irans...than one new Irada which you propose to build and pay $£ 120,000$ for." 70 Nevertheless, Bertie telegraphed Tom that he would visit Belfast to conclude the matter, but he had not given his uncle full information.

Tom reacted strongly, but in the process laid out what he saw as the proper way of handling negotiations and signalling.

Now as regards the new boat...we ought to get her with all improvements at $£ 120,000$ and that you should stick at this \& not pay more until you have to - Yet in spite of this you express your intention of going out hot foot in a desperate hurry to see Clarke who if he wants the job should come to

\footnotetext{
${ }^{67}$ Ibid., 7 March 1901 (Tom to Bertie).

${ }^{68} \mathrm{NMM}, \mathrm{CL}, \mathrm{BAT} 2 / 7,19$ April 1901 (to Tom).

${ }^{69}$ Ibid., 20 April 1901 (to Syd).

${ }^{70}$ UL, DSCA, D641/4/62, 22 April 1902 (Tom to Bertie).
} 
see you - It is no business of a shipowner to go to see a builder the price $\&$ terms etc should be settled in your office not his - You say Barclay Curle \& Swan Hunter have all been asked why ask them unless you wait for their replies both as to price and possible delivery - At even $£ 120,000$ remember she will be a [dear] ship when she is finished for prices will fall further yet...- The fact of your going over to Belfast would show [your] anxiety - (I have none) and if I were the seller would put on at least a couple of thousand on to the price...Orders for ships are scarce and will be scarcer - You have never seen a bad time since you have been in the office and have much to learn. ${ }^{71}$

The uncle advised his nephew to collect bids from all builders before making a final decision lest he waste their time and acquire a reputation as a perfidious dealer. He told Bertie to assert his position by conducting the negotiations in his own office and to avoid signalling his eagerness. Above all, he should stick to his price. Tom clearly expected hard times ahead. In a follow-up letter written the same day, the older man revealed that he fully understood the phased nature of the negotiating process by telling his nephew that "[i]f you let them know you are prepared to build with them provided terms price \& delivery can be arranged \& ask both Workman and Clarke to come over they will come if they want the job." 72 Indicating that one was seriously considering a deal was appropriate, but acting anxious was not.

In the event, Bertie entertained bids from other yards, which revealed that Workman Clarke's price was the lowest and that they could deliver the ship before the beginning of the cotton season, which in his view was crucial. Moreover, the Belfast builder was considering other offers and needed a quick decision. Bertie made the error of concluding the deal in their office, and admitted to Tom that he had much to learn. ${ }^{73}$ The new ship entered service just before the market turned down in the spring of 1902; Tom had accurately foreseen the recession.

${ }^{71}$ Ibid.

${ }^{72}$ Gordon Boyce, "Network Knowledge and Network Routines: Negotiating Activities between Shipowners and Shipbuilders," Business History, XLV, No. 2 (2003), 52-76.

${ }^{73} \mathrm{NMM}, \mathrm{CL}, \mathrm{BAT} 2 / 7,23$ April 1901 (to Tom). 


\section{The Trades}

The steamers' voyage accounts, which run from 1902 to 1915, reveal several distinct trades that the Bates served on a regular basis (see table 2).

Table 2

Deployment of the Steamer Fleet

$\begin{array}{lcc}\text { Trade } & \begin{array}{c}\text { Number of } \\ \text { Voyages }\end{array} & \begin{array}{c}\text { Percentage } \\ \text { of Time }\end{array} \\ \text { UK/Europe-India } & 48 & 30.12 \\ \text { UK/Europe-US Cotton ports (Galveston and } & & \\ \quad \text { New Orleans) } & 38 & 17.90 \\ \text { UK/Europe-Burma Rice ports (Rangoon and Bassein) } & 16 & 16.74 \\ \text { UK/Europe-East Asia (Indonesia, Japan and China) } & 9 & 11.95 \\ \text { Other } & 6 & 4.03 \\ \text { Charters } & 13 & 19.26\end{array}$

Source: National Maritime Museums (NMM), Caird Library (CL), BAT 7.

The category "other" in table 2 includes a few trades that the Bates' ships served intermittently: the Black Sea grain route and UK-South Africa. A few of these voyages were linked, or undertaken as extensions to the more frequently served routes. For example, Istrar (voyage 67) took a coal cargo to South Africa and then proceeded to India to bring home cotton, seeds and ore. Overall, the core operating theatre of the fleet consisted of trades with India, the southern US, East Asia and Burma. The fleet was engaged in charter work nearly twenty percent of the time.

The Bates operations in the US cotton trade were centred at the Texas port of Galveston and run jointly with Welsford. The shipping season lasted from October to March or April each year. Voyage times varied from fortyseven to 169 days, including time at sea and in port. The average trip took seventy-nine days, of which 39.7 were at sea and 39.3 in port. Thus, ships actually earned revenue only about half the time.

Most westward voyages were undertaken in ballast; of the thirty-eight trips made by Bates' ships, only twelve carried coal outwards to the US or South America. The vessels mostly carried cotton eastwards, but they also brought some grain, general cargo and timber. Usually they made only one bunkering stop, at Newport News, Virginia, unless they made the outward run to South America, a longer trip that necessitated refuelling in the Caribbean. For nineteen voyages the ships discharged at Liverpool; eleven trips ended at Bremen and the remaining eight stopped at French, Dutch or Belgian ports. Therefore, continental demand was as important as that generated by Liverpool 
mills. After discharging, the vessels proceeded in ballast to Barry or Cardiff to take on bunkers and sometimes an outward coal cargo.

The India trade ran from June to October, thereby complementing the cotton season. The average trip between Europe and Colombo, Kurrachee or Bombay took 108 days, with eighty-three days being the shortest and 177 the longest. Days in port (fifty-one) almost equalled those steaming (fifty-seven). The ships made 2.6 fuelling stops, excluding bunkering at terminal ports. The cost of the Suez Canal was high (over £1000), but this seldom induced Bates to take the Cape route except once when rates were absolutely dismal. Obtaining a cargo of coal for Port Said or Indian ports was vital to profitability.

Indeed, on nearly every trip (forty-seven of forty-eight), Bates' ships carried coal outwards. The records list the nature of homebound cargoes for only eleven voyages, which consisted mostly of seeds, manganese ore and cotton. Cargoes bound for Europe originated primarily from Bombay (31.5) and Kurrachee (12.5), and most homeward trips terminated at continental ports, including Dunkirk (fourteen), Antwerp (ten) or other French, Italian and German centres (4.5). UK ports of call included Hull (eleven), London (2.5), Dundee (two) and Liverpool (1.5). From these terminals, the ships proceeded in ballast to Welsh ports to procure outbound coal freights and take on bunkers. Thus, most of the the company's Indian trade involved shipments to Europe rather than the UK, and outbound coal cargoes loomed large in the operation.

Bates' ships made sixteen voyages in the rice trade from Rangoon or Bassein. Sometimes they undertook side trips to India or the Black Sea, but on average a rice voyage took 180 days, with the shortest being eighty-six and the longest occupying 305 days. On average, the steamers spent seventy-two days at sea and 112 in port, reflecting slow loading at Burmese ports. They also usually made four bunkering stops per round trip. Outward coal cargoes were important in this trade. Of the sixteen trips, fourteen involved coal exports and just two were in ballast. After discharging coal at Indian ports, the vessels proceeded empty to Rangoon (eleven) or Bassein (five). The rice cargoes usually went to the continent; only one voyage terminated at a British port (London).

Bates' East Asian and Pacific voyages involved calls at a variety of ports in Indonesia, China, Japan, Australia and the east and west coasts of the United States. In many instances, the ships made voyage legs in the company's established trades as part of a complex pattern of movement. As examples, on voyage 49 Iran took coal to Japan, called at Rangoon for rice bound for Italy and then proceeded to Odessa to load grain for Rotterdam; on voyage 39 Imani took coal from Wales to India via the Cape, loaded sugar in Indonesia for New York and travelled to Galveston to pick up cotton for Liverpool. Bates chartered some ships for a single leg within the overall voyage.

The East Asian trips, of which there were nine, were much longer than the India, Galveston and Burma runs. The average voyage was 228.4 
days, with 128 at sea (fifty-six percent of the voyage time). The longest trip was 310 days and the shortest was 101 . The average number of ports visited per voyage amounted to 14.6 with 10.3 bunkering stops. On all nine voyages the ships carried coal outwards. Onward cargoes were not always available at ports of discharge, and the vessels had to travel in ballast on an average of 1.8 legs in each voyage to secure an onward freight. Minimizing ballast trips was a key indicator of how well one practised "the difficult art of tramp ship management," but it is impossible to assess the Bates capacity in the absence of comparative data.

The longest of all the voyages made by Bates steamers were charters. (These are distinguished from the East Asian voyages which involved only one chartered leg per total trip in that the ships were hired out on two or more legs; on this basis, the purpose of the trip was to execute a charter.) Of the thirteen voyages, two were conducted on time charters, while in four cases the Bates negotiated a rate for a complete voyage. In the remaining seven instances they concluded a charter for several voyage legs, usually after shipping coal from Wales (six trips) to get the ship in position. Similarly, the firm booked a cargo to bring a ship home at the end of a charter. An example of both strategies was Istrar's fifty-second voyage in which it took coal outwards from Wales to New York in order to accept a charter to Australia, followed by another charter to India, and then proceeded in ballast to Burma to accept a rice freight to Holland. The firm booked time charters for voyages from England to Australia via the Cape (two), whole voyage charters to the west coast of South America (three) and from the UK to Australia via the Cape (one). The partial charters involved trips to Australia, India, Indonesia and the United States. The charter trips were very long, averaging 255 days; the longest occupied 586 days and the shortest 116 .

"Other" voyages involved an assortment of trades. Three of the six so classified were in the Black Sea grain trade. Two outbound trips were operated in ballast, while the other involved a coal cargo to Port Said and then a run in ballast to Odessa. The remaining trips consisted of runs to South America and thence to either India or the US. The last voyage was an India via the Cape trip. All three voyages involved outward coal cargoes.

\section{The Cross Trades and Coal Cargoes}

Craig observed that tramps sometimes ran between foreign ports for years

without returning home. About thirty percent of Britain's pre-1914 fleet worked in the so-called "cross trades" where the national fleet had competitive advantages. Table 3 shows the Bates' heavy involvement in this sector; carrying bulk goods from the colonies and the US to Europe was the cornerstone of the Bates' operations. Moreover, apart from the cotton trade, outbound coal cargoes were important in positioning ships for cross-trade voyages. Bertie 
recognized this flexibility in vessel deployment when he wrote to Tom that having secured an outbound coal cargo from Wills and Co. to Port Said it would be relatively easy to send Istrar "anywhere." 74 The same was true for the charter business; the family carried coal outwards to position vessels in every instance bar one (where case oil was shipped) when they needed to position a ship for onward charters. In contrast, no outward cargo was conveyed when they arranged time charters and contracts for ships starting from the UK. Table 4 gives a detailed view of non-charter voyage patterns.

Table 3

Bates' Fleet Cross Trade Operations, 1902-1915

$\begin{array}{lccccc}\text { Trade } & \begin{array}{c}\text { Total } \\ \text { Voyages }\end{array} & \begin{array}{c}\text { Cross-trade } \\ \text { Voyages }\end{array} & \text { Percent } & \begin{array}{c}\text { Voyages with } \\ \text { Outbound Coal }\end{array} & \text { Percent } \\ \text { India } & 48 & 45 & 94 & 44 & 98 \\ \text { Cotton } & 38 & 26 & 68 & 13 & 46 \\ \text { Rice } & 16 & 1 & 100 & 14 & 93 \\ \text { Far East } & 9 & 9 & 100 & 9 & 100 \\ \text { Other } & 6 & 4 & 67 & 4 & 100 \\ \text { Total } & 117 & 100 & 85 & 84 & 83\end{array}$

Notes: A cross-trade voyage is one where at least one leg ran between two non-UK ports; charters are excluded because the hirer determined ship employment

Source: See table 2 .

Table 4

Non-Charter Voyage Patterns of the Bates Fleet

\begin{tabular}{|c|c|c|c|c|c|c|c|c|}
\hline \multirow[b]{2}{*}{$\begin{array}{l}\text { Trade } \\
\text { Route }\end{array}$} & \multicolumn{4}{|c|}{ 2-Way } & \multicolumn{2}{|c|}{ Triangular } & \multicolumn{2}{|c|}{ Multilateral } \\
\hline & UK & $\begin{array}{c}\text { UK } \\
\text { (w/ } \\
\text { Coal) }\end{array}$ & $\begin{array}{c}\text { Cross- } \\
\text { Channel }\end{array}$ & $\begin{array}{l}\text { Cross- } \\
\text { Channel } \\
\text { (w/coal) }\end{array}$ & $\begin{array}{l}\text { Trian- } \\
\text { gular }\end{array}$ & $\begin{array}{c}\text { Triangular } \\
\text { (w/coal) }\end{array}$ & $\begin{array}{l}\text { Multi- } \\
\text { lateral }\end{array}$ & $\begin{array}{l}\text { Multi- } \\
\text { lateral } \\
\text { (w/coal) }\end{array}$ \\
\hline India & 0 & 3 & 0 & 12 & 0 & 21 & 0 & 12 \\
\hline Cotton & 12 & 0 & 11 & 0 & 1 & 6 & 2 & 5 \\
\hline Rice & 0 & 0 & 2 & 1 & 0 & 8 & 0 & 5 \\
\hline Far & & & & & & & & \\
\hline East & 0 & 0 & 0 & 0 & 0 & 1 & 0 & 8 \\
\hline Other & 1 & 1 & 0 & 0 & 1 & 1 & 0 & 2 \\
\hline Total & 13 & 4 & 13 & 13 & 2 & 37 & 2 & 32 \\
\hline
\end{tabular}

Note: See text for definitions of voyage types

Source: See table 2 .

${ }^{74}$ Ibid., BAT 2/4, 21 February 1900 (to Tom). 
The data show that straightforward home-and-back voyages were relatively few (seventeen). Few of the UK direct trips involved outbound coal freights due to the large proportion of voyages in the cotton trade from the US where there was little demand for coal. Half of the ships conducting two-way trips with a cross-Channel run (twenty-six) discharged on the continent, made a ballast trip to load coal in the UK, and then began another outward leg. Most of the other half consisted of vessels in the cotton trade, and these headed straight back to the US. Triangular voyages (thirty-nine) may or may not have involved a cross-Channel ballast run, but they did include an intermediate leg between two distant ports (for example, out from the UK, discharge at Port Said, in ballast to Bombay and returning to the UK or the continent). The vast majority of these voyages included a coal trip outwards. Multilateral trips (thirty-four) consisted of more than three voyage legs not counting crossChannel runs. Again, the majority involved outbound coal.

Aggregating the voyages into two main groups - "all two-way" (UK two-way and two-way cross-Channel) ${ }^{75}$ and "complex" (triangular and multilateral) voyages - reveals that for two-thirds of them (seventy-four out of 118 trips) the Bates fleet was primarily engaged in complicated trades involving numerous legs. Thus, the trading spheres identified previously conceal the complexity of tramping. Moreover, what would appear to be a straightforward out-and-back trade, such as cotton, in fact involved "complex" voyages much of the time (fourteen out of thirty-eight trips). The same can be said for the India trade - neither was similar to the shuttle-type services run by liner companies. Finally, every trade except for the "all two-way" cotton business relied very heavily on outbound coal.

The period during which the Bates were active coal carriers was marked by important changes in the structure of the seaborne coal trade. While Britain remained the dominant supplier, India, Japan and the US entered geographically adjacent markets. Increasingly, British collieries sold directly to large customers, including railways, utilities and shipping firms. The trend began in the London coastal trade and then spread to other sectors in the 1890s. A number of shipping companies, including Cory and Furness Withy, built up sizeable "integrated" businesses that combined coal mining with shipping and distribution at home and abroad. Many large shipping enterprises bought directly from independent collieries and carried supplies to their own foreign depots. "Market-based" foreign bunkering was arranged on the basis of annual contracts in which a bunkering firm agreed to supply a shipowner at several ports; to the extent that the bunkering firms did not transport their own supplies, they employed non-aligned shipping firms, like Bates and Sons, to

\footnotetext{
${ }^{75}$ Technically, two-way cross-Channel voyages should be classified as a triangular trade as I explain below.
} 
perform this function. ${ }^{76}$ Within the context of a diminishing scope for middlemen, it is significant that the Bates were able to retain an intermediary position in the coal trade. Their ability to do so reflected their product knowledge, connections and long experience as merchants.

In the export sector of the market, the sparse evidence shows that the family not only bought its own fuel from a stable of collieries to "make favour" but also carried coal repeatedly for the same customers. ${ }^{77}$ Bates' ships conveyed bunkers to Port Said and India for several shipping firms, including Ellerman, Messageries, Ellerman, Bibby, British India, P\&O and Holt subsidiaries (to whom they also chartered vessels). Further, the Bates made numerous shipments to India for a stable of six coal owners/distributors, including Wills and Co., from whom the family also bought their own bunkers. In addition, the Bates shipped coal on their own account for sale in India on twelve occasions, representing twenty-five percent of the voyages they made to that colony. It is obvious that the Bates' Indian connections were important in supporting their intermediary capacity as coal shipper and merchant.

The records do not indicate that acting as a shipper for collieries and buying their own cargoes - that is, performing a merchant function - generated tension between the Bates and colliery owners and distributors. The fact that repeat dealing endured suggests that acting in a dual capacity did not create serious problems. Indeed, it is possible that when they purchased coal cargoes, the Bates gave collieries access to markets that they would otherwise not have served. Nor did the Bates see any conflict in shipping coal to India for shipping firms, such as the Bibby Line, P\&O, Ellerman and the French liner firm Messageries, which also ran to the subcontinent. ${ }^{78}$ The equipoise between competition and co-operation in the maritime sector has been noted above.

The evidence drawn from the Bates papers challenges the view that the market for coal exports was "perfect." The Bates networks provided superior information, generated goodwill that supported repeat dealing with collieries and customers, and provided advantageous outlets. The volatility of freight rates and futures prices suggests that information flows were erratic and subject to distortion. Moreover, Bertie's letter to his father in which he stated that had Sedgwick known that Alexander had a boat approaching Calcutta they could have "work[ed] the rate up" reveals that there was scope for manipulat-

${ }^{76}$ For contracting arrangements, see Kirkaldy, British Shipping, 459-460. Church, History, 73 and 78-79 discusses changes in distribution.

${ }^{77}$ There were other segments within the coal-carrying business; the Bates shipped fuel between Indian ports, and their sailing vessels took Australian coal to the west coasts of the US and South America.

${ }^{78} \mathrm{NMM}, \mathrm{CL}, \mathrm{BAT} 7$, Voyage Accounts. 
ing prices. These indicators of market imperfections have a direct bearing on the debate about the importance of coal exports.

Harley's framework is based on the assumption that the market was perfect and that rates were determined by "joint production" within the context of a two-way trade (that is, homeward and outbound prices were interdependent in that high rates in one direction had a tendency to depress prices on the other voyage leg). ${ }^{79}$ This foundation for analysis has already been questioned with respect to market perfection, while the preceding discussion of Bates and Sons' voyages revealed patterns of considerable complexity. Even if two-way cross-Channel ballast trips are treated as bilateral, which strictly speaking they were not, the fleet was seldom engaged in back-and-forth shuttle operations; indeed, this type of business resembled liner services rather than tramping. The assumption that joint production influenced rates on related voyage legs is also undermined by evidence that Bertie frequently booked a homeward cargo and then cast about for an outbound fixture. (In contrast, owners often dispatched a ship with an outward freight, having no homeward bound fixture, and instructed the master to stop at an intermediate port "for orders" regarding the return trip.) These practices, along with indications that shipowners could withhold information about the timing of arrivals, suggest that the market would have had difficulty determining rates on the basis of joint production even where a two-way shuttle service was viable.

Table 5 shows the percentage of total freight revenue accounted for by outbound coal shipments for voyages in the various operating spheres. In every instance, except the cotton trade, coal receipts were significant. While the Bates did not work the short-haul trades between the UK and the continent where these exports were heaviest and where, as Harley observed, the British merchant marine lost ground to foreign rivals, their involvement in coal shipments to distant ports in South and East Asia, where the nation's fleet did retain a greater market share, is noteworthy. While any downward impact that outbound shipments may have had on homeward rates, as Harley suggests may have existed, cannot be estimated, it is clear that coal freights were sufficiently significant that without them many of the Bates' trades simply would not have been viable. The poor results achieved in the Galveston trade are a case in point; even with twelve outbound coal freights, the firm lost money on nearly half its voyages (eighteen of thirty-eight). Without any coal exports, the Bates

\footnotetext{
${ }^{79}$ The figures Harley, "Coal Exports," uses in his model show adjustments within a two-leg voyage. His snap-shot analyses, which include only years of falling rates or recession, consist of two-way trips in the North Sea (1909); coal outward to France and ore homebound from Spain (with no account for the ballast trip between France and Spain, 1909-1910); UK-Mediterranean-Black Sea run (again, with no account of the intermediate ballast voyage, 1891-1893); UK-Argentina refrigerated service (1908-1909); and a non-refrigerated run from the UK to Buenos Ayres terminating at Genoa (1903-1904).
} 
would have suffered debilitating losses of nearly one-quarter of total freight receipts between 1902 and 1915. Harley's snap-shot analyses do not expose the ongoing importance of coal shipments after Britain established its dominant position during the $1870 \mathrm{~s}$ and $1880 \mathrm{~s}$. From the experience of this firm, it is difficult to accept his conclusions.

Table 5

Outward Coal Shipments, 1902-1914/1915

Trade

India

Cotton

Rice

East Asia

Other

Total

\section{Total Number of Voyages}

\section{Total Number of Shipments}

48
38
16
9
6
117

\section{Outward Coal Freight as Percentage of Total Freight Receipts}

Source: See table 2.

\section{Profitability}

Appendix table 1 presents data for outward and return freight receipts, earnings from the carriage of cargo and commissions for each of the Bates' trades. The results during the recession of 1902-1910 and the recovery from 1911 to 1915 are shown separately to emphasize the severity of the long slump and the recuperative effect of the upswing. Earnings are net only of voyage-related variable costs; other expenses like insurance, depreciation and interest were covered in the capital accounts.

The figures reveal that the Bates' trades were not well balanced in terms of outward and homebound freights. Given the large number of outbound ballast trips, it is not surprising that cotton was the most highly skewed, while the East Asian sector was the least. In addition, the latter trade was the only one to include intermediate legs that generated earnings; these profits had an important impact on overall results. Thus, to a large extent the Bates' business depended on inward freight.

During the recession the firm sustained losses on forty-six voyages and made modest profits on the fifty-one trips that generated positive results. The poorest sector in terms of performance was the India trade; the other main trading areas produced small average profits, while chartering was the most lucrative business. When they could be secured, charters were good business in bad times. The other sustaining element during the recession was commis- 
sion earnings where the firm made $£ 17,479$ versus a loss of $£ 1266$ on noncharter voyages. This comparison confirms the insight Lewis Fischer and Anders Fon derived from their study of Fearnley and Eger that commissions were an important and steady source of income. ${ }^{80}$ Indeed, chartering and commission earnings put the firm into an overall profit position during the slump.

During the subsequent recovery, the cotton and rice trades were the best earners, while the single voyage to East Asia also produced a strong result. Chartering, however, remained the best performer. During the five-year boom, Bates earned a total of $£ 88,630$ on all voyages compared with $£ 13,802$ for the recession years. Commissions were significant but were comparatively less important in the good times. On the basis of voyage profits, the recovery did bring consolation (but see below).

Table 6

Earnings per Day, 1902-1914/1915, for Various Activities

\begin{tabular}{llc} 
Trade & & Earnings Per Day $(\mathfrak{f})$ \\
India & $1902-1910$ & {$[3.99]$} \\
& $1910-1914 / 1915$ & 12.46 \\
Cotton & $1902-1914 / 1915$ & 1.37 \\
& $1902-1910$ & 2.13 \\
Rice & $1911-1914 / 1915$ & 34.64 \\
& $1902-1914 / 1915$ & 8.87 \\
\multirow{3}{*}{ East Asia } & $1902-1910$ & 2.80 \\
& $1911-1914 / 1915$ & 20.58 \\
& $1902-1914 / 1915$ & 8.84 \\
Other & $1902-1910$ & 1.71 \\
& $1911-1914 / 1915$ & 14.65 \\
& $1902-1914 / 1915$ & 3.02 \\
& $1902-1910$ & 1.74 \\
Charters & $1911-1914 / 1915$ & 14.65 \\
& $1902-1914 / 1915$ & 11.67 \\
& $1902-1914 / 1915$ & 6.10 \\
& $1902-1911$ & 6.80 \\
& $1901-1914 / 1915$ & 27.20 \\
& $1902-1914 / 1915$ & 13.63
\end{tabular}

Source: See table 2 .

For the entire 1902-1915 period, the following sectors contributed to total earnings $(£ 128,407)$ as follows: commissions 20.2 percent, chartering

${ }^{80}$ Lewis R. Fischer and Anders M. Fon, "The Making of a Maritime Firm: The Rise of Fearnley and Eger, 1859-1917," in Fischer (ed.), From Wheel House to Counting House: Essays in Maritime Business History in Honour of Professor Peter Neville Davies (St. John's, 1992), 303-322. 
35.2 percent and the main trades 45.6 percent. Since all of the latter's contributions came after 1910, it was the most important branch of the business during the recovery. A more precise way to assess profitability, however, is to examine earnings over time. Table 6 indicates how much the Bates earned per day in various operations during the recession and the recovery. Between 1902 and 1911, chartering was the most profitable employment followed, albeit a long way back, by the rice and cotton trades. Indian operations were a losing proposition, while the East Asian and "other" trades were profitable but produced pitiful results. The recovery, when it came, generated impressive results. The Galveston run was the most profitable, followed by chartering, the rice trade, East Asia, India and "other."

Earnings for the period as a whole do not reveal any relationship between profits and coal exports. The cotton and rice businesses produced almost the same levels of profit, while the former attracted few outbound coal freights. It is true that fuel exports were most important in the India trade, which generated the poorest results, but the East Asian sector also relied on coal and performed twice as well. It seems reasonable to conclude that variables other than coal shipments had a greater impact on the profits shaped by homebound rates that sustained the competitive positions of specific firms.

Overall, the data indicate that Aldrcoft was correct in suggesting that shipping firms struggled desperately during the recession and barely scraped through. But to obtain a broader view of the firm's performance it is necessary to consider capital costs as well. The Bates records do not include all the data needed to make a comprehensive assessment, but they do contain the prices paid for two vessels, Iran and Imani; from this information extrapolations can be made (see table 7). The proportion of equity to debt is assumed to be the same as that which the Bates used for Irada; that is, the conservative balance of thirty-six percent in shares and sixty-four percent in debentures. ${ }^{81}$ The figures indicate that during the worst of the recession Iran made only about ten percent of its total costs while Imani did slightly better (about twelve percent). Neither ship recouped these losses during the prewar upswing; over the period as a whole, the former made only enough to meet twenty percent of its costs while the latter covered half its expenses. Even if debenture interest is excluded for Iran, which in fact had no outstanding debt by 1902, the results were still poor. These figures explain why many owners used self-insurance and consumed capital by avoiding depreciation payments. The results clearly reveal just how bad the recession was and justifies Aldcroft's dire description. Indeed, across the cycle the financial results for these two ships were insufficient to render their operations sustainable on a long-term basis. Rising ship

\footnotetext{
${ }^{81} \mathrm{NMM}, \mathrm{CL}, \mathrm{BAT} 2 / 4$, n.d. [c. 20 May 1900] (to Syd) and 25 May 1900 (to Tom).
} 
values between 1911 and 1913 and then into World War I must have saved many a shipowner from ruin.

Table 7

Earnings and Fixed Costs for Iran and Imani, 1902-1914

\begin{tabular}{|c|c|c|c|c|c|c|c|}
\hline Iran & $\begin{array}{l}\text { Depre- } \\
\text { ciation }\end{array}$ & $\begin{array}{l}\text { Debenture } \\
\text { Redemption }\end{array}$ & $\begin{array}{l}\text { Debenture } \\
\text { Interest }\end{array}$ & Insurance & $\begin{array}{l}\text { Total } \\
\text { Costs }\end{array}$ & Earnings & Shortfall \\
\hline $\begin{array}{l}1902- \\
1910\end{array}$ & $£ 31,500$ & $£ 21,150$ & $£ 11,416$ & $£ 13,860$ & $£ 77,926$ & $£ 7723$ & {$[£ 70,203]$} \\
\hline $\begin{array}{l}1911- \\
1914\end{array}$ & 14,000 & 9400 & 1885 & 2560 & 27,845 & 15,359 & {$[£ 12,446]$} \\
\hline $\begin{array}{l}1902- \\
1914\end{array}$ & 45,500 & 30,550 & 13,301 & 16,420 & 105,771 & 23,082 & {$[£ 92,649]$} \\
\hline Imani & $\begin{array}{l}\text { Depre- } \\
\text { ciation }\end{array}$ & $\begin{array}{c}\text { Debenture } \\
\text { Redemption }\end{array}$ & $\begin{array}{l}\text { Debenture } \\
\text { Interest }\end{array}$ & Insurance & $\begin{array}{l}\text { Total } \\
\text { Costs }\end{array}$ & Earnings & Shortfall \\
\hline $\begin{array}{l}1902- \\
1910\end{array}$ & $£ 20,356$ & $£ 13,870$ & $£ 7760$ & $£ 9131$ & $£ 41,986$ & $£ 5429$ & {$[£ 38,566]$} \\
\hline $\begin{array}{l}1911- \\
1914\end{array}$ & 11,000 & 6701 & 1830 & 2385 & 21,916 & 20,754 & [£1162] \\
\hline $\begin{array}{l}1902- \\
1914\end{array}$ & 31,356 & 20,571 & 9590 & 11,516 & 63,902 & 26,183 & {$[£ 39,728]$} \\
\hline
\end{tabular}

Notes: Depreciation charged at five percent on a straight-line basis (from an initial figure determined by deducting five percent per year between the time the ship was built and when the voyage accounts began in 1902); debentures redeemed on a five percent straight-line basis; debenture interest charged at five percent on outstanding amounts; and insurance charged at four percent on the depreciated value of the ship (non-British North American rate)

Source: See table 2.

\section{Conclusion}

This essay has examined the intricacies of tramp shipping, its relationship with coal exports and the impact of acute cyclical fluctuations during a period when Britain's merchant marine had a dominant share of world trade. The study provides a counterpoint to other works that consider broader trends and aggregate data. The Bates papers give us a firm-level view of changing conditions within a turbulent sector of the industry.

This small family enterprise was atypical in that it operated a mixed fleet, retained traditional structures and combined tramp shipping with merchant trading and banking. While the company was behind the times in some respects, its conservative policies had advantages. Merchant activities helped the family secure cargoes when demand was poor and played a role in sustaining the firm's intermediary position in the coal trade to India. At certain times, and on specific routes on the fringe of steam operations, sailing vessels gener- 
ated impressive voyage profits. Yet the Bates firm relied on speed for competitive advantage in the steam sector and built a large, advanced, twin-screw ship, Irada, for the cotton trade. The records provide a valuable glimpse into a business in transition.

The Bates correspondence also furnishes an unusual, if not unique, perspective on "the difficult art of tramp ship management" by revealing how a young man acquired the requisite knowledge and skills with help from far more experienced relatives. This was indeed a challenging task that required knowledge of many commercial and technical variables, conditions in distant regions and numerous commodities. As Bertie learned, he also made mistakes that reveal unexpected aspects of "the art" and the consequences of getting something wrong. ${ }^{82}$ Faced with a volatile market in which rates and therefore income levels might suddenly change, it was incumbent upon the tramp owner to develop an eye for identifying and minimizing costs. The most vital skill was matching moving ships with changing cargo flows. This called for the development of a mental image of an environment in flux and the capacity to anticipate events. The young manager had to learn how to anticipate and see several moves ahead when positioning vessels. He had to develop judgment and a measure of intuition. As veteran tramp owner Walter Runciman wrote about the timing of ship purchases, "instinct must decide as it has heretofore done." ${ }^{83}$ Many aspects of tramp management called for the same attribute, as well as other seemingly tacit skills, such as negotiating, that could be learned by grasping cognitive frameworks. Dealing with builders, suppliers, competitors and customers was a necessary skill, as was learning how to manage information that arrived in a torrent. Overall, the fledgling tramp manager needed contextual knowledge, anticipatory capacity, "soft skills" and a global perspective to operate successfully in a service industry intimately connected to the so-called "first international economy."

Operating tramps was a high-stress activity. Risk was ever-present and diverse; wars, pestilence, market dislocations, currency fluctuations, accidents and breakdowns could occur at any moment. Change was a constant. As Tom told Bertie, "in these times events move quickly and business changes and every year or day even that one is out of the running one's opinion about current business becomes less valuable. ${ }^{84}$ Moreover, the clock never stopped ticking for tramp owners. Increments of time shaped their calculations of prof-

${ }^{82}$ Through his letters a modern reader also discovers unexpected things: coal was not a homogenous commodity but was subject to numerous variations that could confound decisions regarding bunkering, cargo purchasing and export shipments.

${ }^{83}$ Italics added. University of Glasgow (UG), Business Records Centre (BRC), UGD 255/2/15/16, Sir Walter Runciman to J.G. Humble, 10 October 1921.

${ }^{84}$ UL, DSCA, D 641/4/62, 26 November 1901 (Tom to Bertie). 
its and costs, as did delays caused by loading and discharging, and heavy interest payments had to be met at regular intervals. The only way to stay on top of time was to keep the vessels "moving," that is, earning.

Most of the trades worked by the Bates involved complex voyage patterns. Few were simple two-way shuttles. The cross trades were paramount. Within each trading sphere there were several sub-sectors, some defined by commodity or trip configuration. Cotton dominated the Galveston run, whereas the Baltimore trade was comprised of a mix of cargoes. Moreover, the tramping sector was not homogeneous; it consisted of merchant-to-shipowner hiring, long-term contracts, chartering and shipowner-purchased cargo shipping. Further, chartering had sub-sections: time, voyage, government, hiring by merchants or other shipowners and participating arrangements. For the Bates, chartering was the best business; other, much larger firms, including Furness Withy and its affiliate, British Maritime Trust, developed substantial businesses based on three- to five-year charters at rates that covered interest, insurance, depreciation and a predictable level of profit. ${ }^{85}$ Across all its different tramping activities, Bates and Sons depended heavily on outbound coal freights.

The aggregate data and snap-shot analyses that Harley employed to raise questions about the importance of coal exports for British shipping conceal its significance for individual firms over relatively long periods. Equilibrium models and voyage data relevant to two or three years cannot expose the dynamics of the business. The structure of this trade changed from 1890 as distribution methods shifted and new sources developed. Some shipowners, like the Bates, maintained intermediary positions, while others like Cory and Furness built up substantial "quasi-integrated" operations. Indeed, Furness set up offshore coal distribution facilities that acted as bridgeheads for developing a much wider business at ports like Rotterdam and Antwerp, and during the prolonged recession his coal offices achieved extremely rapid growth. ${ }^{86}$ The Bates voyage patterns were far more complex than the two-way shuttle services Harley examined, and the market governing the trade was far from perfect. The firm's records confirm that coal exports represented a large proportion of total freight earnings, but the data reveal no correlation between profits and the incidence of outbound fuel shipments as Harley suggested.

${ }^{85}$ Boyce, Rise and Dissolution.

${ }^{86}$ Ibid. Some of Furness's coastal colliers achieved a twenty-five percent return on investment in 1907, a level of earnings that prompted a near doubling of the fleet over the next few years; Furness Withy, Directors' Minutes, 27 July 1907. From 1905 to 1910 , in the depths of the recession, the turnover achieved by the Newcastle and Cardiff offices, both of which handled large quantities of exports, rose from $£ 137,935$ to $£ 536,129$, representing 3.6 and 10.7 percent, respectively, of the firm's entire turnover; NMM, FWS A/10/1. 
In a somewhat counterfactual way, it could be argued that the collapse of coal exports after World War I reflected the importance of this trade. Buxton and Palmer cited the decline as confirmation of just how bad conditions could be in the absence of this outbound cargo. Walter Runciman instinctively recognized that the slump in the coal and wheat markets heralded hard times, and his nephew knew of owners who would gladly have accepted a marginally profitable cross trade but could not take it without an outbound cargo ${ }^{87}$ The impact of the collapse after 1919 is clear, and it seems that before 1914 factors other than the coal trade influenced firm performance.

The evidence indicates that the Bates obviously struggled during the prolonged recession. Survival for many companies must have depended on containing operating costs and astutely timing tonnage purchases during the mid-1890s dip in the cycle. The recovery boosted voyage profits, but the Bates firm still did not meet its capital expenses. It is evident that the family consumed capital from 1902 to 1915 despite its financial conservatism. Companies that bought new ships in the 1908-1909 trough would have benefitted enormously from the rise in shipping values that began in 1911 and continued into the war. Indeed, the global conflict probably saved a number of tramping firms. It is possible that some tramp owners held on during bad times hoping to make a proverbial killing during the upturn that experience had taught them would come eventually. The turn-of-the-century peak, the prewar recovery and the wartime boom provided opportunities to sell, and many shipowners did. Few were as sage as Runciman, who sold thirteen ships (71,087 tons) at the top of the cycle in 1919 for a rumoured $£ 20$ per ton and two years later repurchased the fleet at about $£ 2.5$ per ton. The Turnbulls also sold in the boom and re-entered in the slump, while Radcliffe did not spend its insurance proceeds from war losses until the 1920s. ${ }^{88}$

The Bates evidence may suggest that the tramp sector was in structural decline before World War I. From the beginning of steam propulsion, there was a trend for liners to displace tramps when the volume and value of cargo rose sufficiently to make regularly scheduled service viable. The pattern continued, but many trades that did not meet this requirement; indeed, the growing complexity of global commerce created new opportunities for tramps. Furness, Runciman and other veterans successfully exploited these interstices and developed remunerative, long-term chartering and contract businesses.

${ }^{87}$ UG, BRC, UGD255/2/15/16, Philip to Uncle Walter, 29 September 1921.

${ }^{88}$ Long and Long, Shipping Venture, 193-194; and Jenkins, Evan Thomas Radcliffe, 34-37. UG, BRC, UGD 255/2/15/16, Runciman to Humble, 10 October 1921 , mentions $£ 2.5$ per ton. Years later, Denis Bates still despised Runciman for these transactions because he exploited uninformed investors and diminished the collective reputation of shipowners. UL, DSCA, D 641/3/48, Denis Bates Diary, entry for 16 October 1946. 
Significantly, both entrepreneurs had a feel for the cycle and consistently bought ships during slumps. Success in tramping depended greatly on a sense of timing that came with experience. ${ }^{89}$

Perhaps the Bates did poorly because their fleet was managed by novices; both Bertie and Percy were in their twenties. As the letters reveal, Uncle Tom had a good feel for the ebb and flow of the business, yet he allowed Bertie to order a large vessel on the brink of the 1902 slump. Perhaps he felt his nephew could only learn by making his own mistakes, costly though they might be.

The Bates family did make the transition from tramp to liner operations under Percy's leadership, although it is not clear why. Bertie had no desire to develop lines; when Welsford suggested they form a joint scheduled service from Galveston, Bertie replied that he "wouldn't hear of it" and said that he wanted to be able to pull out of a trade "at a moment's notice." ${ }^{90}$ Percy may have had a different outlook. He was actively pursuing the acquisition of a line for some time before he took a stake in Brocklebanks, for he bid against Furness for the Glen Line in 1910. ${ }^{91}$ Percy was perhaps more ambitious (in more than one way) and had wider opportunities than his short-lived brother.

${ }^{89} \mathrm{UG}$, BRC, UGD 255/2/15/6, contains a fleet list (dated December 1904) detailing average annual returns on capital for twenty-three ships purchased between 1892 and 1903 that ranged from 3.62 to 19.44 percent, with an average of about eleven percent. This record shows the advantages of buying tonnage in downturns and of deploying new units as rates rose. Philipp Runciman described his uncle's ability to predict market movements as "scary," writing to Humble that "I am frightfully loth [sic] to argue with the Chief because his foresight and prophesies on the trend of things to come have been so marvellously true, uncanny..." UGD 255/2/15/16, 7 October 1921.

${ }^{90} \mathrm{NMM}, \mathrm{CL}, \mathrm{BAT} 2 / 4,30$ May 1900 (to Tom).

${ }^{91}$ Furness Withy, Directors' Minutes, 21 July 1910. For further details on the Bates family history, see Boyce, "Language and Culture." 
Copyright of International Journal of Maritime History is the property of International Journal of Maritime History and its content may not be copied or emailed to multiple sites or posted to a listserv without the copyright holder's express written permission. However, users may print, download, or email articles for individual use. 